\title{
Busy Board: Evidence from CEOs and Director's Compensation
}

\author{
Robin Robin \\ Universitas Internasional Batam, Indonesia \\ *Corresponding Author: robin@uib.ac.id
}

\begin{abstract}
This paper examines the busy board and compensation for CEO and independent directors. The independent variable is the busy board. The sample cover 12.332 observations during the period from 1996 to 2015. The analysis is used unbalanced panel data. In this paper, the methods that used to prove the hypothesis are using regression and econometric methodology. The results show that firms with busy boards likely to increase the CEO and independent director's compensation. The results also support the hypothesis when eliminating the endogeneity problem. Further, the results are also significant positive when changing the measurement of CEO and independent director's compensation for robustness results. This research suggests that the busy board is weaker the corporate governance.
\end{abstract}

Keywords $\quad$ : Busy Board; CEO; Corporate Governance; Excess Compensation; Independent Director

JEL Classification : G15, G30

\section{INTRODUCTION}

The job of a director in the firm becomes heavy because they need to spend a lot of time. The CNBN mentions that each director spends an average 62.5 hours a week, increase from 44 hours per week according the Bureau of Labor Statistics (Berger, 2018). However, the increases in spending time have not represented the effectiveness of monitoring and advising. In the previous research, a busy board is a director who holds three or more positions in the main firm and outside the firm. Also, the previous studies mention that a busy board is weaker corporate governance. For example, Hong et al. (2016) mention that firms with more friendly board likely to pay higher compensation and direct incentives affective increase CSR (corporate social responsibility) performance.

This study tested the effect of the busy board on CEO and independent director compensation. The independent variable is a categorical scale. If the firm has a director who holds three or more positions in the firm or outside firm than equals to one and zero if a director who holds less than three positions (Chen and Guay, 2019). To avoid the differences of a firm size and CEO power that could affect the compensation, the measurement of compensation uses the residual from total compensation regression (Hill et al., 2016). 
The data is collected 12,332 sample from United States firms between 1996 until 2015. The results show that the busy board is significant and positive on CEO and independent director's compensation. Further, the firms with the higher busy board likely weaker the corporate governance roles and likely to pay the CEO and independent director's higher salaries to maintain their loyalty to the firms and avoid them move to other firms. For the robustness results, in this paper also control firm, corporate governance, and independent director characteristics. For example, one standard deviation increases in busy board increase $54.69 \%$ of CEO's compensation and $61.14 \%$ of independent director's compensation.

One of the main concerns is the endogeneity problem. One method that allows to address this problem is the Propensity Score Matching (PSM) method. PSM is the method that allows to address the sample selection bias (Lin et al., 2018). Further, the dependent variable that measures by residual value from total compensation regression with the excess compensation. The excess compensation for CEO is the salary, bonus, or both. The excess compensation for independent directors is cash, stock, option, and equity.

The contributions of this research included: first, this is the first research that examines the effect of a busy board on CEO and independent director's compensation. The measurement not only uses the nominal of the compensation that the CEO and independent directors received but also use the excess compensation and residual value from total compensation regression. Hill et al. (2016) mention that uses the nominal of the compensation is associated with the CEO power and firm size and the excess compensation is not economically justified. In this paper also control several variables include firm characteristics, corporate governance characteristics, and independent director characteristics. When all control variables run into the regression, the busy board still have a strong and significant effect on CEO and independent director's compensation. These results also support Hong et al. (2016) that weak corporate governance allows increases compensation. Second, this study also contributes to the corporate governance literature. The busy board representative the weak corporate governance monitoring and advising. Third, this study also extends the compensation literature. The busy board is a director that has a lot of network connection that firm trusted to serve as an independent director.

\section{HYPOTHESES DEVELOPMENT}

\section{Busy board}

In the previous research found that the benefits and threats from the busy board. Garner et al. (2017) mention that busy board reflect a weaker corporate governance in the firms. Hauser (2018) mention that reduce the independent director's activities in other firms increase the primary firm's profit. This is because the independent directors are more focus to monitoring and advising the firms. Further, the CEO who hold a position in other firms also increases the profit for the primary firms if the CEO reduce their activities in other firms. Chen and Guay (2019) find the satisfaction of stakeholders is lower if the independent directors hold a position in other firms because their time is limited. However, the stakeholders agree that independent directors who hold several positions in other firm have a value for advising the firms. Furthermore, the previous studies mention that independent directors who hold several position in other firms likely to decrease the firm performance and firm's value (Hauser, 2018; Masulis and Zhang, 2019; Stein and Zhao, 2019). 
On the other hand, previous studies also mention the benefits of a busy board. Elyasiani and Zhang (2015) mention that the benefits of busy boards are (1) primary firms with located in the central of the business district are likely to hire busy independent director form other firms, (2) the busy board provides monitoring and advising that can increases the quality of the loans that can reduce the default risk, (3) the busy board also has the ability to face in the crisis period, and (4) busy board is not proven to increase the probability of troubled director. Chakravarty and Rutherford (2017) mention that busy board has a ability to obtain more and higher quality advice, thus gaining higher trust which can reduce the costs. Ferris et al. (2020) mention that busy board is decrease the firm's profit, but not for new firms because their need more advise.

\section{Corporate governance}

Hong et al. (2016) find that lower stockholders likely to pay higher compensation for CEO to increases their performance in the society and the society activities can be profitable for the firms and reduce the costs. Halioui et al. (2016) mention that the structure of the corporate governance and the compensation for CEO has an effect on reducing the tax aggressiveness. Friendly board and busy board are also categorized as weaker corporate governance. Based on the previous studies, the hypothesis are as follows:

$\mathrm{H}_{1}$ : Busy board increases CEO compensation.

$\mathrm{H}_{2}$ : Busy board increases independent director's compensation.

\section{METHOD, DATA, AND ANALYSIS}

\section{Sample and data}

This study uses secondary data from the public firm listed on the New York Stock Exchange (NYSE), NASDAQ, and the American Stock Exchange (AMEX). The firm characteristics data come from the Compustat database. CEO and director data come from the RiskMetrics database. Further, the stock price data comes to the Center for Research in Security Prices (CRSP). The total sample in this study was 12,332 observations during the period from 1996 to 2015 (excluding financial firm with the SIC code 60006999). For balanced panel data is required all firm available from 1996 until 2015 and the number of samples will be drastically reduced. In this study using unbalanced panel data is to avoid the number of missing data. The benefit of uses panel data is that results are generalizable.

\section{Busy board measurement}

The Busy board is a director that hold three or more position in the outside of the firms. This measurement is following by Chen and Guay (2019) and busy board is a dummy variable. To measure the busy board, the variable set one if the director who holds three or more positions and set zero if the director who holds less than three position. The reason why using the busy board is following Chen and Guay (2019) than busy boards are difficult to allocate their time to monitoring and advising the firms.

\section{Compensation measurement}

The dependent variables in this research are compensation for CEO and independent directors. First, the excess compensation for CEO is measure by estimate the residual value from total compensation regression that includes firm size, ROA, leverage, board size, board independency, board age board tenure, female director, and year and industry fixed effects. Second, the excess compensation for the independent director is 
measure by the estimate of the residual value from total compensation regression that includes firm size, ROA, leverage, board size, board independency, board age board tenure, female director, and year and industry fixed effects.

\section{Control variables}

Based on the previous studies, the control variables include firm, corporate governance, and independent director characteristics that influences the busy board on compensation for CEO and independent directors. All of variables are uses in firm $i$ with year $t-1$. The firm characteristics include: (1) return on assets $(R O A)$ is the total income divided by total assets. (2) one-year stock return (Return) is the return in one year. (3) leverage (Lev) is the total debts divided by total assets. (4) dividend (Div) is the total dividend divided by total assets. (5) firm size $(F S)$ is the one plus logarithm of total assets. The corporate governance characteristics include: (1) board size (BZ) is the one plus logarithm of total number of board size. (2) board independency (BI) is the total independent directors divided by board size. The independent director characteristics include: (1) female director $(F D)$ is equal to one if the have a female director and zero is otherwise. (2) director age $(D A)$ is the one plus logarithm of average age of independent directors. (3) director tenure $(D T)$ is the one plus logarithm of average tenure of independent directors.

\section{RESULTS}

\section{Statistic descriptive}

Table 1 shows the statistic descriptive of the busy board, compensation for CEO, compensation for independent directors, and control variables. All of the variables are winsorized at $1 \%$ and $99 \%$ to address the outliers. The average of the busy board $(B B)$ is 0.0017 with 0.4980 of standard deviation. The average of excess compensation for the CEO $(E C C)$ is 0.0017 . the average of excess compensation for independent directors (ECID) is 0.0006. Both of the average compensation for CEO and independent directors are higher than industry average compensation. The average ROA is $5.25 \%$ and Return is $12.38 \%$. the average dividend (Div) is $34.47 \%$. the average board size $(B S)$ is 8 directors with $74.46 \%$ are independent directors.

Table 1. Statistic descriptive

\begin{tabular}{lccccc}
\hline \multicolumn{1}{c}{ Variable } & $\mathbf{N}$ & Mean & Min & Max & Std Dev \\
\hline ECC & 11,759 & 0.0017 & -6.0556 & 4.2517 & 0.9647 \\
ECID & 11,377 & 0.0006 & -6.5200 & 4.5758 & 0.7391 \\
BB & 12,332 & 0.0017 & 0.0000 & 1.0000 & 0.4980 \\
ROA & 12,290 & 0.0525 & -0.3209 & 0.2577 & 0.0804 \\
Return & 12,215 & 0.1238 & -0.7694 & 1.7450 & 0.4183 \\
Lev & 12,253 & 0.2191 & 0.0000 & 0.7116 & 0.1709 \\
Div & 12,259 & 0.3447 & 0.0000 & 5.7975 & 1.0072 \\
FS & 12,290 & 6.9035 & 0.0000 & 11.6270 & 1.4896 \\
BS & 12,328 & 2.1705 & 0.0000 & 3.2958 & 0.2836 \\
BI & 12,328 & 0.7446 & 0,2500 & 1.0000 & 0.1541 \\
FD & 12,328 & 0.6861 & 0.0000 & 1.0000 & 0.4641 \\
DA & 12,328 & 4.0040 & 0.0000 & 4.4037 & 0.3521 \\
DT & 12,328 & 2.0442 & 0.0000 & 3.4340 & 0.6436 \\
\hline All & & & &
\end{tabular}

All of the variable is winsorized at $1 \%$ and $99 \%$. 
Table 2 shows the difference t-test. Mostly the variables are significant at $1 \%$ level. The result shows that the busy board is positive and significantly on compensation for CEO and independent directors.

Table 2. High and low busy board characteristics

\begin{tabular}{lcccc}
\hline \multicolumn{1}{c}{ Variable } & High BB & Low BB & mean diff & t-stat \\
\hline ECID & 0.2180 & -0.1833 & $0.4013^{* * *}$ & $(22.98)$ \\
ECC & 0.0941 & -0.0789 & $0.1730^{* * *}$ & $(12.52)$ \\
ROA & 0.0503 & 0.0543 & $-0.0040^{* * *}$ & $(-2.74)$ \\
Return & 0.1132 & 0.1327 & $-0.0195^{* * *}$ & $(-2.56)$ \\
Lev & 0.2458 & 0.1968 & $0.0490^{* * *}$ & $(15.98)$ \\
Div & 0.5227 & 0.1966 & $0.3261^{* * *}$ & $(18.08)$ \\
FS & 7.0127 & 6.8124 & $0.2003^{* * *}$ & $(7.44)$ \\
BS & 2.2387 & 2.1052 & $0.1435^{* * *}$ & $(28.91)$ \\
BI & 0.7757 & 0.7187 & $0.0570^{* * *}$ & $(20.80)$ \\
FD & 0.7863 & 0.6024 & $0.1839^{* * *}$ & $(22.34)$ \\
DA & 4.0004 & 4.0069 & -0.0065 & $(-1.02)$ \\
DT & 2.1414 & 1.9630 & $0.1784^{* * *}$ & $(15.48)$
\end{tabular}

This table show the difference between high and low busy board. Superscripts *, **, and *** means significance at the $10 \%, 5 \%$, and $1 \%$ levels.

\section{Busy board and compensation for CEO and independent directors}

To analyze the effect of a busy board on compensation for CEO and independent directors, a model developed as follows:

$$
E C C_{i, t}=\alpha_{0}+\alpha_{1} B B_{i, t-1}+\boldsymbol{\theta}^{\prime} \boldsymbol{Z}_{i, t-1}+\gamma_{i}+\mu_{t}+\varepsilon_{i, t}
$$

(1)

$$
E C I D_{i, t}=\alpha_{0}+\alpha_{1} B B_{i, t-1}+\boldsymbol{\theta}^{\prime} Z_{i, t-1}+\gamma_{i}+\mu_{t}+\varepsilon_{i, t}
$$

(2)

Notes:

$E C C_{i, t}=$ the excess compensation estimated by the residual value for total compensation for $\mathrm{CEO}$ regression.

$E C I D_{i, t}=$ the excess compensation estimated by the residual value for total compensation for independent director regression.

$B B_{i, t-1}=$ a dummy variable than equal to one if the director who holds three or more positions and zero if the director who holds less than three positions.

$Z_{i, t-1}=$ the control variables from corporate governance characteristics and firm characteristics.

$\gamma_{i} \quad=$ the industry fixed effect.

$\mu_{t} \quad=$ the year fixed effect.

$\varepsilon_{i, t} \quad=$ the error of the regression. 
Table 3 and Table 4 show that the coefficient of the busy board is significant on compensation for CEO and independent directors. The coefficient of 0.0937 and 0.2051 means that the busy board is positive and significant on compensation for CEO and independent directors. Further, the firms with a high busy board increase a $54.69 \%$ $\left(\mathrm{e}^{(0.0937)} \times 0.4980\right)$ compensation for the CEO per one standard deviation. Also, the firms with a busy board increase a $61.14 \%\left(\mathrm{e}^{(0.2051)} \mathrm{x}\right.$ 0.4980) compensation for independent directors per one standard deviation. Therefore, the increases in the busy board on compensation for CEO and independent directors are economically important. Firms are likely to pay higher compensation to the $\mathrm{CEO}$ and independent directors to keep them stay in the firms. These results also support to Acharya and Volpin (2010).

Table 3. Busy board and compensation for CEO

\begin{tabular}{|c|c|c|c|c|}
\hline & $(1)$ & (2) & (3) & (4) \\
\hline Constant & $\begin{array}{c}0.2480 \\
(0.65)\end{array}$ & $\begin{array}{l}-0.1197 \\
(-0.49)\end{array}$ & $\begin{array}{l}-0.6300 \\
(-1.42)\end{array}$ & $\begin{array}{c}-0.6926^{*} \\
(-1.92)\end{array}$ \\
\hline$B B$ & $\begin{array}{c}0.1856^{* * *} \\
(7.41)\end{array}$ & $\begin{array}{c}0.1348^{* * *} \\
(5.52)\end{array}$ & $\begin{array}{c}0.1145^{* * *} \\
(4.75)\end{array}$ & $\begin{array}{c}0.0937^{* * *} \\
(3.95)\end{array}$ \\
\hline$R O A$ & & $\begin{array}{c}0.5584^{* * *} \\
(3.63)\end{array}$ & & $\begin{array}{c}0.6184^{* * *} \\
(4.14)\end{array}$ \\
\hline Return & & $\begin{array}{c}0.1590^{* * * *} \\
(7.03)\end{array}$ & & $\begin{array}{c}0.1652^{* * *} \\
(7.32)\end{array}$ \\
\hline Lev & & $\begin{array}{c}0.0837 \\
(0.95)\end{array}$ & & $\begin{array}{c}0.0184 \\
(0.22)\end{array}$ \\
\hline Div & & $\begin{array}{c}0.1062^{* * *} \\
(7.15)\end{array}$ & & $\begin{array}{c}0.0925^{* * *} \\
(6.09)\end{array}$ \\
\hline FS & & $\begin{array}{c}0.0893^{* * *} \\
(9.44)\end{array}$ & & $\begin{array}{c}0.0879^{* * *} \\
(9.13)\end{array}$ \\
\hline$B S$ & & & $\begin{array}{c}0.1974^{* * *} \\
(3.44)\end{array}$ & $\begin{array}{c}0.0518 \\
(0.85)\end{array}$ \\
\hline$B I$ & & & $\begin{array}{c}0.5811^{* * *} \\
(4.15)\end{array}$ & $\begin{array}{c}0.5683^{* * *} \\
(4.18)\end{array}$ \\
\hline$F D$ & & & $\begin{array}{l}0.0501 \\
(1.38)\end{array}$ & $\begin{array}{c}0.0318 \\
(0.91)\end{array}$ \\
\hline$D A$ & & & $\begin{array}{l}0.0335 \\
(0.64)\end{array}$ & $\begin{array}{c}0.0424 \\
(0.69)\end{array}$ \\
\hline DT & & & $\begin{array}{c}-0.1501^{* * *} \\
(-4.31)\end{array}$ & $\begin{array}{c}-0.1755^{* * *} \\
(-5.19)\end{array}$ \\
\hline Control for: & & & & \\
\hline Year FE & Yes & Yes & Yes & Yes \\
\hline Industry FE & Yes & Yes & Yes & Yes \\
\hline Obs. & 11,377 & 11,227 & 11,377 & 11,227 \\
\hline Adj. $R^{2}$ & 0.0274 & 0.0689 & 0.0517 & 0.0886 \\
\hline
\end{tabular}

Where the dependent variable is compensation for CEO (ECC). BB is a dummy variable than equal to one if the director hold three or more position and zero if the director hold less than three positions. $\gamma_{i}, \mu_{t}$, and $\varepsilon_{i, t}$ are firm and year fixed effect and the error of the regression. Superscripts ${ }^{*}, * *$, and ${ }^{* * *}$ means significance at the $10 \%, 5 \%$, and $1 \%$ levels. 
Table 4. Busy board and compensation for independent directors

\begin{tabular}{|c|c|c|c|c|}
\hline & (1) & (2) & (3) & $(4)$ \\
\hline Constant & $\begin{array}{c}0.4150 \\
(1.17)\end{array}$ & $\begin{array}{c}-1.4171^{* * *} \\
(-4.16)\end{array}$ & $\begin{array}{c}-1.8440^{* * *} \\
(-4.96)\end{array}$ & $\begin{array}{c}-2.7322^{* * *} \\
(-6.87)\end{array}$ \\
\hline$B B$ & $\begin{array}{c}0.4188^{* * *} \\
(12.77)\end{array}$ & $\begin{array}{c}0.2800^{* * *} \\
(9.74)\end{array}$ & $\begin{array}{c}0.2629^{* * * *} \\
(8.49)\end{array}$ & $\begin{array}{c}0.2051^{* * *} \\
(7.36)\end{array}$ \\
\hline$R O A$ & & $\begin{array}{c}1.7277^{* * *} \\
(10.54)\end{array}$ & & $\begin{array}{c}1.7542^{* * *} \\
(10.70)\end{array}$ \\
\hline Return & & $\begin{array}{c}0.3906^{* * *} \\
(16.64)\end{array}$ & & $\begin{array}{c}0.3954^{* * *} \\
(16.73)\end{array}$ \\
\hline Lev & & $\begin{array}{c}0.3903^{* * *} \\
(3.64)\end{array}$ & & $\begin{array}{c}0.2665^{* *} \\
(2.53)\end{array}$ \\
\hline Div & & $\begin{array}{c}0.3015^{* * *} \\
(12.37)\end{array}$ & & $\begin{array}{c}0.2565^{* * *} \\
(10.80)\end{array}$ \\
\hline$F S$ & & $\begin{array}{c}0.2025^{* * *} \\
(15.89)\end{array}$ & & $\begin{array}{c}0.1826^{* * *} \\
(14.12)\end{array}$ \\
\hline$B S$ & & & $\begin{array}{c}0.7516^{\star * *} \\
(11.00)\end{array}$ & $\begin{array}{c}0.3998^{* * *} \\
(6.26)\end{array}$ \\
\hline$B I$ & & & $\begin{array}{c}0.6452^{* * *} \\
(4.78)\end{array}$ & $\begin{array}{c}0.5530^{* * *} \\
(4.55)\end{array}$ \\
\hline$F D$ & & & $\begin{array}{c}0.1136^{* * *} \\
(2.96)\end{array}$ & $\begin{array}{c}0.0689^{* *} \\
(2.04)\end{array}$ \\
\hline$D A$ & & & $\begin{array}{c}0.0807 \\
(1.51)\end{array}$ & $\begin{array}{c}0.0851 \\
(1.42)\end{array}$ \\
\hline$D T$ & & & $\begin{array}{l}-0.0468 \\
(-1.08)\end{array}$ & $\begin{array}{c}-0.0931^{* *} \\
(-2.39)\end{array}$ \\
\hline \multicolumn{5}{|l|}{ Control for: } \\
\hline Year FE & Yes & Yes & Yes & Yes \\
\hline Industry FE & Yes & Yes & Yes & Yes \\
\hline Obs. & 11,759 & 11,601 & 11,759 & 11,601 \\
\hline Adj. $R^{2}$ & 0.0565 & 0.2166 & 0.1144 & 0.2364 \\
\hline
\end{tabular}

Where the dependent variable is compensation for CEO (ECID). BB is a dummy variable than equal to one if the director hold three or more position and zero if the director hold less than three positions. $\gamma_{i}, \mu_{t}$, and $\varepsilon_{i, t}$ are firm and year fixed effect and the error of the regression. Superscripts $*, * *$, and ${ }^{* * *}$ means significance at the $10 \%, 5 \%$, and $1 \%$ levels.

\section{Endogeneity problem}

In this part, the busy board sorted into high (treatment) and low (control) with a busy board. Matching uses 4 different methods: (1) Nearest neighbor $(n=1),(2)$ Nearest neighbor ( $n=2)$, (3) Gaussian Kernel, and (4) Kernal Epanechnikov. Panel A and B of Table 5 show the differences between treatment and control firms.

Table 5. Propensity score matching (PSM)

Panel A Matching estimation: differences of Compensation_ID between treatment and control firms

\begin{tabular}{lcccc}
\hline Matching Methods & Treatment & Control & Difference & t-Statistics \\
\hline Near neighbour $(\mathrm{n}=1)$ & 0.0915 & 0.0300 & $0.0615^{* * *}$ & $(2.83)$ \\
Near neighbour $(\mathrm{n}=2)$ & 0.0915 & 0.0310 & $0.0605^{* * *}$ & $(3.06)$ \\
Kernel Gaussian & 0.0915 & 0.0099 & $0.0816^{* * *}$ & $(4.98)$ \\
Kernel Epanechnikov & 0.0915 & 0.0215 & $0.0700^{* * *}$ & $(4.04)$ \\
\hline
\end{tabular}

Panel B Matching estimation: differences of Compensation_CEO between treatment and control firms 


\begin{tabular}{lcccc} 
Matching Methods & Treatment & Control & Difference & t-Statistics \\
\hline Near neighbour $(\mathrm{n}=1)$ & 0.2129 & 0.0802 & $0.1327^{* * *}$ & $(4.67)$ \\
Near neighbour $(\mathrm{n}=2)$ & 0.2129 & 0.0463 & $0.1666^{* * *}$ & $(6.54)$ \\
Kernel Gaussian & 0.2129 & 0.0189 & $0.1940^{* * *}$ & $(9.15)$ \\
Kernel Epanechnikov & 0.2129 & 0.0402 & $0.1727^{* * *}$ & $(7.75)$ \\
\hline
\end{tabular}

Superscripts *, **, and ${ }^{* * *}$ means significance at the $10 \%, 5 \%$, and $1 \%$ levels.

\section{Robustness tests}

To shows that the busy board is significant and positive on CEO and independent director's compensation, the excess compensation for CEO and independent directors divided into: (1) salary excess compensation for CEO, (2) bonus excess compensation for CEO, (3) salary and bonus excess compensation for CEO, (4) cash excess compensation for independent directors, (5) stock excess compensation for independent directors, (6) option excess compensation for independent directors, and (7) equity excess compensation for independent directors. In Table 6, the results still support the hypothesis. The higher busy board increase the excess compensation for CEO and independent directors.

Table 6. Robustness tests

\begin{tabular}{|c|c|c|c|c|c|c|c|}
\hline & (1) & (2) & (3) & (4) & (5) & (6) & (7) \\
\hline & $\begin{array}{l}\text { CEO } \\
\text { Salary }\end{array}$ & $\begin{array}{l}\text { CEO } \\
\text { Bonus }\end{array}$ & $\begin{array}{c}\text { CEO Salary + } \\
\text { Bonus }\end{array}$ & ID Cash & ID Stocks & $\begin{array}{c}\text { ID } \\
\text { Options }\end{array}$ & $\begin{array}{c}\text { ID } \\
\text { Equity }\end{array}$ \\
\hline \multirow[t]{2}{*}{ Constant } & $-1.1354^{* * *}$ & $-1.0414^{* * *}$ & $-1.2263^{* * *}$ & $0.8148^{* * *}$ & $3.4972^{\star * *}$ & 0.4702 & -0.5583 \\
\hline & $(-3.76)$ & $(-3.13)$ & $(-4.04)$ & $(-4.01)$ & $(-5.29)$ & $(0.79)$ & $(-1.35)$ \\
\hline$B B$ & $\begin{array}{c}0.0794^{* * *} \\
(5.63)\end{array}$ & $\begin{array}{c}0.1207^{* * *} \\
(4.25)\end{array}$ & $\begin{array}{c}0.0922^{* * *} \\
(5.80)\end{array}$ & $\begin{array}{c}0.0709^{* * *} \\
(3.11)\end{array}$ & $\begin{array}{c}0.2221^{* * *} \\
(4.40)\end{array}$ & $\begin{array}{c}-0.0084 \\
(-0.13)\end{array}$ & $\begin{array}{c}0.1106^{* * *} \\
(4.42)\end{array}$ \\
\hline$R O A$ & $\begin{array}{c}0.3505^{* * *} \\
(3.70)\end{array}$ & $\begin{array}{c}0.8422^{* * *} \\
(4.64)\end{array}$ & $\begin{array}{c}0.4138^{* * *} \\
(4.19)\end{array}$ & $\begin{array}{c}0.0894 \\
(0.66)\end{array}$ & $\begin{array}{c}0.4888 \\
(1.61)\end{array}$ & $\begin{array}{c}1.5388^{* * *} \\
(3.95)\end{array}$ & $\begin{array}{c}1.0779^{* * *} \\
(6.32)\end{array}$ \\
\hline Return & $\begin{array}{c}0.0932^{* * *} \\
(6.48)\end{array}$ & $\begin{array}{c}0.2995^{* * *} \\
(10.18)\end{array}$ & $\begin{array}{c}0.1492^{* * *} \\
(9.64)\end{array}$ & $\begin{array}{c}-0.0073 \\
(-0.38)\end{array}$ & $\begin{array}{c}0.0501 \\
(1.31)\end{array}$ & $\begin{array}{c}0.1921^{* * *} \\
(3.79)\end{array}$ & $\begin{array}{c}0.2226^{* * *} \\
(8.86)\end{array}$ \\
\hline Lev & $\begin{array}{c}0.0951^{*} \\
(1.69)\end{array}$ & $\begin{array}{c}-0.2079^{*} \\
(-1.90)\end{array}$ & $\begin{array}{c}0.0738 \\
(1.15)\end{array}$ & $\begin{array}{c}0.0522 \\
(0.60)\end{array}$ & $\begin{array}{c}0.7150^{* * *} \\
(3.92)\end{array}$ & $\begin{array}{c}-0.7212^{* * *} \\
(-2.92)\end{array}$ & $\begin{array}{c}-0.1864^{*} \\
(-1.79)\end{array}$ \\
\hline Div & $\begin{array}{c}0.1231^{* * *} \\
(11.53)\end{array}$ & $\begin{array}{c}0.1369^{* * *} \\
(6.37)\end{array}$ & $\begin{array}{c}0.1404^{* * *} \\
(11.62)\end{array}$ & $\begin{array}{c}0.1027^{* * *} \\
(6.28)\end{array}$ & $\begin{array}{c}0.1787^{* * *} \\
(6.14)\end{array}$ & $\begin{array}{c}-0.0569 \\
(-1.31)\end{array}$ & $\begin{array}{c}0.1091^{* * *} \\
(5.50)\end{array}$ \\
\hline$F S$ & $\begin{array}{c}0.0888^{* * *} \\
(13.90)\end{array}$ & $\begin{array}{c}0.1054^{* * *} \\
(8.84)\end{array}$ & $\begin{array}{c}0.0982^{* * *} \\
(13.75)\end{array}$ & $\begin{array}{c}0.0712^{* * *} \\
(7.53)\end{array}$ & $\begin{array}{c}0.1126^{* * *} \\
(5.49)\end{array}$ & $\begin{array}{c}0.0227 \\
(0.78)\end{array}$ & $\begin{array}{c}0.0877^{* * * *} \\
(7.36)\end{array}$ \\
\hline$B S$ & $\begin{array}{c}0.1996^{* * *} \\
(5.65)\end{array}$ & $\begin{array}{c}0.1536^{* *} \\
(2.31)\end{array}$ & $\begin{array}{c}0.2195^{* * *} \\
(5.37)\end{array}$ & $\begin{array}{c}0.2308^{* * *} \\
(4.56)\end{array}$ & $\begin{array}{c}0.4804^{* * *} \\
(4.19)\end{array}$ & $\begin{array}{c}-0.3007^{* *} \\
(-2.05)\end{array}$ & $\begin{array}{l}-0.0865 \\
(-1.12)\end{array}$ \\
\hline$B I$ & $\begin{array}{c}0.2341^{* * *} \\
(3.21)\end{array}$ & $\begin{array}{l}0.1921 \\
(1.35)\end{array}$ & $\begin{array}{c}0.1355^{*} \\
(1.69)\end{array}$ & $\begin{array}{c}0.1130 \\
(0.95)\end{array}$ & $\begin{array}{c}1.6834^{* * *} \\
(8.08)\end{array}$ & $\begin{array}{c}0.2819 \\
(0.99)\end{array}$ & $\begin{array}{c}0.3628^{* * *} \\
(2.67)\end{array}$ \\
\hline$F D$ & $\begin{array}{c}0.0474^{* * *} \\
(2.61)\end{array}$ & $\begin{array}{c}0.0610 \\
(1.57)\end{array}$ & $\begin{array}{c}0.0638^{* * *} \\
(3.07)\end{array}$ & $\begin{array}{c}0.1218^{* * *} \\
(3.71)\end{array}$ & $\begin{array}{c}0.2187^{* * *} \\
(3.28)\end{array}$ & $\begin{array}{c}-0.0383 \\
(-0.45)\end{array}$ & $\begin{array}{c}-0.0353 \\
(-0.97)\end{array}$ \\
\hline$D A$ & $\begin{array}{c}0.0246 \\
(0.93)\end{array}$ & $\begin{array}{c}-0.0202 \\
(-0.55)\end{array}$ & $\begin{array}{c}-0.0074 \\
(-0.29)\end{array}$ & $\begin{array}{c}0.0594^{*} \\
(1.78)\end{array}$ & $\begin{array}{l}0.1161 \\
(0.86)\end{array}$ & $\begin{array}{c}0.0281 \\
(0.28)\end{array}$ & $\begin{array}{l}0.0208 \\
(0.37)\end{array}$ \\
\hline DT & $\begin{array}{c}-0.0583^{* * *} \\
(-2.93)\end{array}$ & $\begin{array}{l}-0.0613 \\
(-1.55)\end{array}$ & $\begin{array}{c}-0.0395^{*} \\
(-1.71)\end{array}$ & $\begin{array}{c}0.0038 \\
(0.12)\end{array}$ & $\begin{array}{c}0.3235^{\star * * *} \\
(-4.99)\end{array}$ & $\begin{array}{c}0.0361 \\
(0.43)\end{array}$ & $\begin{array}{c}0.1171^{* * *} \\
(-3.13)\end{array}$ \\
\hline \multicolumn{8}{|l|}{ Control for: } \\
\hline & Yes & Yes & Yes & Yes & Yes & Yes & Yes \\
\hline $\begin{array}{l}\text { Industry } \\
F E\end{array}$ & Yes & Yes & Yes & Yes & Yes & Yes & Yes \\
\hline Obs. & 11,597 & 10,792 & 11,597 & 11,714 & 11,701 & 11,713 & 10,608 \\
\hline Adj. $R^{2}$ & 0.1824 & 0.0620 & 0.1754 & 0.0891 & 0.1165 & 0.0214 & 0.0690 \\
\hline
\end{tabular}


Where the dependent variables are the excess salary for CEO (CEO Salary), the excess bonus for CEO (CEO Bonus), the excess salary and bonus for CEO (CEO Salary + Bonus), the excess cash for independent directors (ID Cash), the excess stocks for independent directors (ID Stocks), the excess options for independent directors (ID Excess), and the excess equity for independent directors (ID Equity). $B B$ is a dummy variable than equal to one if the director hold three or more position and zero if the director hold less than three positions. $\gamma_{i}, \mu_{t}$, and $\varepsilon_{i, t}$ are firm and year fixed effect and the error of the regression. Superscripts *, **, and ${ }^{* * *}$ means significance at the $10 \%, 5 \%$, and $1 \%$ levels.

\section{DISCUSSION}

In the Table 3 and 4 , the results show that the busy board increases the CEO and independent director's compensation. This means that the firm's with higher busy board is weaker the corporate governance roles. The independent directors spend a limited time in the firms and less monitoring and advising. Further, to keep their position, both CEO and independent directors likely to create a friendly board, where the independent director may serve more than three position in other firms and both can increase their compensation. This results also support the previous studies from Hong et al. (2016) and Garner et al. (2017). The results address the endogeneity problem. One of the problems is the selection bias. For the robustness tests, the excess compensation for CEO (ECC) and independent directors $(E C I D)$ are replace with are the excess salary for CEO (CEO Salary), the excess bonus for CEO (CEO Bonus), the excess salary and bonus for CEO (CEO Salary + Bonus), the excess cash for independent directors (ID Cash), the excess stocks for independent directors (ID Stocks), the excess options for independent directors (ID Options), and the excess equity for independent directors (ID Equity). Further, the results are support the hypothesis that higher busy board increase the excess compensation for $\mathrm{CEO}$ and independent directors. Finally, the busy board is poorer corporate governance.

\section{CONCLUSION}

The previous studies discuss the influences of corporate governance. The proxy for busy board and define the excess compensation for CEO and independent directors following the previous studies. The results show that a higher busy board increases excess compensation for CEO and independent directors. The busy board has limited time in monitoring the firm's activity. In the other side, the firm pay higher compensation to prevent CEO and independent directors move to other firms and prevent the entry of new firm in similar industries. In addition, use the Propensity Score Matching (PSM) method to eliminate the sample selection bias and the results still support the hypothesis. Overall, this paper provides evidence that a busy board has a positive effect on excess compensation for $\mathrm{CEO}$ and independent directors.

\section{Acknowledgment}

This paper is a part of Robin's dissertation when he was a Ph.D. student in College of Management, Yuan Ze University, Taiwan. This paper also presented in "The $1^{\text {st }}$ INCREDIBLE International Congress on Regional Economic Development, Information Technology, and Sustainable Business" on October 27th, 2020 and received as one of the best paper awards in the Management categories. Thank you to anonym referee and audience for the comments and suggestion.

\section{REFERENCES}

Berger, S. (2018). Harvard study: What CEOs do all day. CNBC. https://www.cnbc.com/2018/06/20/harvard-study-what-ceos-do-all-day.html 
Chakravarty, S., \& Rutherford, L. G. (2017). Do busy directors influence the cost of debt? An examination through the lens of takeover vulnerability. Journal of Corporate Finance, 43, 429-443. https://doi.org/10.1016/j.jcorpfin.2017.02.001

Chen, K. D., \& Guay, W. R. (2019). Busy Directors and Shareholder Satisfaction. Journal of Financial and Quantitative Analysis, 1-30. https://doi.org/10.1017/S0022109019000590

Elyasiani, E., \& Zhang, L. (2015). Bank holding company performance, risk, and "busy" board of directors. Journal of Banking and Finance, 60, 239-251. https://doi.org/10.1016/j.jbankfin.2015.08.022

Ferris, S. P., Jayaraman, N., \& Liao, M. Y. (Stella). (2020). Better directors or distracted directors? An international analysis of busy boards. Global Finance Journal, 44. https://doi.org/10.1016/j.gfj.2018.05.006

Garner, J., Kim, T. Y., \& Yong Kim, W. (2017). Boards of directors: a literature review. In Managerial Finance (Vol. 43, Issue 10, pp. 1189-1198). Emerald Group Publishing Ltd. https:/ / doi.org/10.1108/MF-07-2017-0267

Halioui, K., Neifar, S., \& Abdelaziz, F. Ben. (2016). Corporate governance, CEO compensation and tax aggressiveness: Evidence from American firms listed on the NASDAQ 100. In Review of Accounting and Finance (Vol. 15, Issue 4, pp. 445-462). Emerald Group Publishing Ltd. https:/ / doi.org/10.1108/RAF-01-2015-0018

Hauser, R. (2018). Busy directors and firm performance: Evidence from mergers. Journal of Financial Economics, 128(1), 16-37. https://doi.org/10.1016/j.jfineco.2018.01.009

Hill, M. S., Lopez, T. J., \& Reitenga, A. L. (2016). CEO excess compensation: The impact of firm size and managerial power. Advances in Accounting, 33, 35-46. https://doi.org/10.1016/j.adiac.2016.04.007

Hong, B., Li, Z., \& Minor, D. (2016). Corporate Governance and Executive Compensation for Corporate Social Responsibility. Journal of Business Ethics, 136(1), 199-213. https://doi.org/10.1007/s10551-015-2962-0

Lin, C. Y., Tsai, W. C., Hasan, I., \& Tuan, L. Q. (2018). Private benefits of control and bank loan contracts. Journal of Corporate Finance, 49, 324-343. https://doi.org/10.1016/j.jcorpfin.2018.01.006

Masulis, R. W., \& Zhang, E. J. (2019). How valuable are independent directors? Evidence from external distractions. Journal of Financial Economics, 132(3), 226-256. https://doi.org/10.1016/j.jfineco.2018.02.014

Stein, L. C. D., \& Zhao, H. (2019). Independent executive directors: How distraction affects their advisory and monitoring roles. Journal of Corporate Finance, 56, 199-223. https://doi.org/10.1016/j.jcorpfin.2019.02.003 
Appendix A: Variable definition

\begin{tabular}{|c|c|c|}
\hline Variable & Definition & Data source \\
\hline \multicolumn{3}{|c|}{ Independent variable } \\
\hline$B B$ & $\begin{array}{l}\text { A dummy variable than equal to one if the director who holds } \\
\text { three or more positions and zero if the director who holds less } \\
\text { than three positions. }\end{array}$ & Risk-Metrics \\
\hline
\end{tabular}

\begin{tabular}{|c|c|c|}
\hline \multicolumn{3}{|c|}{ Dependent variables } \\
\hline$E C C$ & $\begin{array}{l}\text { The excess compensation estimated by the residual value for } \\
\text { total compensation for CEO regression. }\end{array}$ & Risk-Metrics \\
\hline$E C I D$ & $\begin{array}{l}\text { The excess compensation estimated by the residual value for } \\
\text { total compensation for independent director regression. }\end{array}$ & Risk-Metrics \\
\hline CEO Salary & $\begin{array}{l}\text { The excess salary estimated by the residual value for total } \\
\text { salary for CEO regression. }\end{array}$ & Risk-Metrics \\
\hline CEO Bonus & $\begin{array}{l}\text { The excess bonus estimated by the residual value for total } \\
\text { bonus for CEO regression. }\end{array}$ & Risk-Metrics \\
\hline $\begin{array}{l}\text { CEO Salary + } \\
\text { Bonus }\end{array}$ & $\begin{array}{l}\text { The excess salary and bonus estimated by the residual value } \\
\text { for total salary and bonus for CEO regression. }\end{array}$ & Risk-Metrics \\
\hline ID Cash & $\begin{array}{l}\text { The excess cash estimated by the residual value for total cash } \\
\text { for independent director regression. }\end{array}$ & Risk-Metrics \\
\hline ID Stocks & $\begin{array}{l}\text { The excess stocks estimated by the residual value for total } \\
\text { stocks for independent director regression. }\end{array}$ & Risk-Metrics \\
\hline ID Options & $\begin{array}{l}\text { The excess options estimated by the residual value for total } \\
\text { options for independent director regression. }\end{array}$ & Risk-Metrics \\
\hline ID Equity & $\begin{array}{l}\text { The excess equity estimated by the residual value for total } \\
\text { equity for independent director regression. }\end{array}$ & Risk-Metrics \\
\hline \multicolumn{3}{|c|}{ Firm characteristics } \\
\hline$R O A$ & The total income divided by total assets. & Compustat \\
\hline Return & The return in one-year. & $\begin{array}{l}\text { Compustat \& } \\
\text { CRSP }\end{array}$ \\
\hline Lev & The total debts divided by total assets. & Compustat \\
\hline Div & The total dividend divided by total assets. & Compustat \\
\hline FS & The one plus logarithm of total assets. & Compustat \\
\hline \multicolumn{3}{|c|}{ Corporate governance characteristics } \\
\hline$B Z$ & The one plus logarithm of total board size. & Risk-Metrics \\
\hline$B I$ & $\begin{array}{l}\text { The total independent directors divided by number of board } \\
\text { size }\end{array}$ & Risk-Metrics \\
\hline \multicolumn{3}{|c|}{ Independent director characteristics } \\
\hline$F D$ & $\begin{array}{l}\text { A dummy variable than equal to one if the firm have a female } \\
\text { director and zero if otherwise. }\end{array}$ & Risk-Metrics \\
\hline
\end{tabular}


$D A$
The one plus logarithm of average age of independent directors.

The one plus logarithm of average tenure of independent directors.
Risk-Metrics

Risk-Metrics 